Published as: Azadi, H., de Jong, S., Derudder, B., De Maeyer, P. \& Witlox, F. (2012), Bitter sweet. How sustainable is bio-ethanol in Brazil? Renewable and Sustainable Energy Reviews, vol. 16(8), pp. 3599-3603.

\title{
Bitter Sweet: How Sustainable Is Bio-Ethanol Production in Brazil?
}

\author{
Hossein Azadi ${ }^{\mathrm{a} 1}$, Sanne de Jong ${ }^{\mathrm{b}}$, Ben Derudder ${ }^{\mathrm{a}}$, Philippe De Maeyer ${ }^{\mathrm{a}}$, Frank Witlox ${ }^{\mathrm{a}}$ \\ ${ }^{a}$ Department of Geography, Ghent University, Belgium \\ ${ }^{b}$ International Relations and International Organisations, University of Groningen, The Netherlands
}

\begin{abstract}
While biofuels have currently been regarded as a good alternative for fossil fuels, there remain many debates on their impacts on human and environment. This paper tried to shed light on bio-ethanol in Brazil as one of the main producers and exporters in the world. The main question was to understand "how sustainable is bio-ethanol production in Brazil?" To answer, the political motives of producing bio-ethanol followed by its ecological and socio-economic impacts were discussed. The paper concluded that although bio-ethanol production in Brazil seems environmentally friendly, it might socio-economically be hazardous.
\end{abstract}

Keywords: Bio-ethanol, biofuels, sugarcane, food security, land use change, sustainability.

\section{Introduction}

Reminding the climate change conference in Copenhagen in December 2009, the issue of reducing $\mathrm{CO}_{2}$ is still very hot. Biofuels are supposed to produce less $\mathrm{CO}_{2}$ emissions and are thereby helpful in reducing the global warming. Such fuels are considered to be a more environmentally friendly alternative than fossil fuels. But do biofuels really

\footnotetext{
${ }^{1}$ Corresponding author. Email: hossein.azadi@ugent.be, Tel. +32 (0)9 26446 95. Fax +32 (0)9 2644985.
} 
improve all the three main (environmental, social, and economic) aspects of 'sustainability'?

At the moment, fossil fuels are still representing 80 percent of the total energy demand of which 20 percent is used by the transport sector. While the demand for energy is growing, the contribution of biofuels to the sector is only one percent. The most used biofuel is bio-ethanol, and Brazil is the first exporter and the second largest producer of bio-ethanol worldwide, after the United States [1]. The total Brazil's bio-ethanol production in 2011 was estimated around 32.5 billion litres of which 90 percent was consumed by Brazil itself. The total export was estimated at 3.2 billion litres in the same year [2].

A simple definition of biofuels is that they are fuels derived from biological sources [3]. The production of ethanol is possible from any biological feedstock that contains a certain amount of sugar or materials (e.g. starch) that can be transformed into sugar. Products that contain sugar are, for example, sugar beets and sugarcane, but also corn, wheat and other cereals contain starch. For the focus of this paper, we will only discuss sugarcane which, in Brazil, is the most commonly used crop to produce ethanol. The sugarcane has to undergo fermentation and becomes alcohol by using yeasts and other microbes. At the final stage, the right concentration of ethanol has to be regulated in order to be blended with gasoline [3].

The issue of bio-ethanol is very complicated and has led to many debates [4-9]. With regard to Brazil, bio-ethanol is highly promoted by different actors but also frequently being questioned because of its effects [10-16]. Among all, one of the main important questions, as for the main focus of this paper, is "how sustainable is the bioethanol production in Brazil?"

This paper is divided to two parts: the first section discusses why bio-ethanol is being produced in Brazil. This will shortly clarify the political motives for producing and using bio-ethanol. The second section examines the sustainability of producing bioethanol in the country by looking at the environmental, social and economic impacts.

\section{Why bio-ethanol is being produced in Brazil?}


In the case of Brazil, more important than environmental issues, there are some political motives for producing and using biofuels in general, and bio-ethanol, in particular. Energy security can be seen as the main political motive for the production and use of biofuels that will reduce the demand for oil [3]. The importance of energy security has regained new focus, because of the tight oil market, and high oil prices [17]. In the time period between 2004 to 2008, the global oil price increased from around 25 to over US\$140 per barrel. Not only the price but also the global demand for oil increased from 64.8 million barrels per day in 1980, to 85 million in 2007 [18]. Beside the growing demand for oil and the increased oil price, the instability of the exporter countries also plays a part [17].

Although the US is the largest producer of bio-ethanol, this country is also the main importer of the Brazilian bio-ethanol. In 2007, the US imported 60 percent of the total 3.5 billion litres bio-ethanol exported by Brazil. Since the US imposes import barriers, the ethanol is imported through third countries in Central America and the Caribbean countries [19]. However, due to new estimation published by The Rio Times in 2011 [20], Brazilian ethanol exports to the US may increase by tenfold over the next decade, due to demand as the US dropped its ethanol import tariffs. Indeed, the US promotes the production of bio-ethanol in Brazil, since, according to Branford [21], this is not only because the US appreciates bio-ethanol as an environmentally friendly product, but also because this country wants to be less dependent on oil. The US wants to work together with Brazil to promote biofuels in the rest of South America. If the US really wants to be environmentally friendly, it has to abolish the tariff rates which are keeping bio-ethanol out of the US market. The overall aim of the US, as Branford [21] emphasizes, is to weaken Chávez and his 'Bolivarian Revolution' as Venezuela is a big oil supplier in the region of South America.

The European Union is a strong promoter of biofuels as well. The EU has clear goals regarding its energy policy. With renewable energy sources, the EU would reduce greenhouse gas (GHG), diversify its energy supply, and stay less dependent on the fossil fuel markets. ${ }^{2}$ To reach these goals, the EU members have set out a Renewable Energy Directive (RED) to promote the use of renewable energy sources. The two main targets

\footnotetext{
${ }^{2}$ http://ec.europa.eu/energy/renewables/index_en.htm
} 
of the RED are that by the year 2020, the 20 percent of the total energy supply, and the 10 percent of the transport sector must come from renewable energy sources. ${ }^{3}$ At the time being, the energy used in the transport sector depends mainly on the imported fossil fuels. ${ }^{4}$ Besides the US, the Netherlands, which plays as an entry port for Europe, and Sweden, are the two other important importers of the Brazilian ethanol [22], respectively 10 and 6 percent [5].

For Brazil, the increased demand for bio-ethanol is very beneficial. It will not only increase the demand for production of ethanol, but also because Brazil is keen on getting a first world status in this regard [23]. Both the States and the EU have become more dependent on the Brazilian bio-ethanol that leads to a stronger position of Brazil in the global economic and political equations.

\section{The impacts of bio-ethanol production on Brazil}

\subsection{Environmental impacts}

Apart from the political motives, the use of bio-ethanol is also promoted for its positive environmental impacts on the climate change. Like other biofuels, bio-ethanol is expected to reduce $\mathrm{CO}_{2}$ emissions but also is considered to be $\mathrm{CO}_{2}$-neutral [1]. But is bioethanol really that environmentally friendly?

One of the problems with producing biofuels is their need to fossil fuels even if in Brazil, compared with other bio-ethanol producer countries, such a need is less felt. In this country, the needed energy for producing ethanol can be generated from waste products instead of fossil fuels. For one unit of ethanol, only 0.1 unit of fossil fuel is needed. This is an advantage compared with ethanol from grain in the States or Europe where the need is 0.6-0.8 unit for one unit of ethanol [3].

Beside such an advantage, there are also negative effects. First of all, the way in which the land is being cultivated for sugarcane has massive effects on the environment. Soil degradation is one of the problems caused by erosion and compaction. Soil erosion is high for sugarcane production due to the time period that land remains bare between the harvest and new cultivation season. The compaction will result from heavy machinery

\footnotetext{
${ }^{3}$ Anticipated indirect land use change associated with expanded use of biofuels and bioliquids in the EU An analysis of the national renewable energy action plans.

${ }^{4}$ http://ec.europa.eu/energy/renewables/biofuels/biofuels_en.htm
} 
which exacerbates soil erosion. The sugarcane production also leads to water and soil pollution caused by the use of fertilizers and the generated by-products [24]. Apart from soil and water pollutions, the use of nitrogen fertilizers causes air pollution since $\mathrm{NO}_{2}$ emissions have stronger effects on nature than $\mathrm{CO}_{2}$ [1]. The expansion of sugarcane farms results in the increased use of fertilizers and therefore causes more pollution [24]. However, according to the International Energy Agency [3], the use of fertilizers in Brazil is still relatively low due to the intensity of the sun and the high productivity of the soils. Another problem with the cultivation is burning the agricultural land. Before harvesting, the straw and leaves of sugarcane is being burnt in order to simplify the manual harvesting. Such burning causes air, water and soil pollution per se [24].

Concerns about deforestation, in particular in the Amazon region, raise the question whether or not the sugarcane production is partly responsible for this. The land that is being used to produce sugarcane for bio-ethanol cannot be used for other agricultural products. However, from the total of 264 million hectares land used for agriculture in Brazil, no more than 2.5 percent is covered by sugarcane. Only in the southeast region of the country, in the state of São Paulo, the land covered by sugarcane is more than 50 percent. In the North, near the Amazon region, the land used for sugarcane is only 0.4 percent out of the total. This is because the sugarcane needs a period of drought which does not occur in the Amazon region [24]. Different studies conclude that the sugarcane production cannot directly be linked to deforestation. A study by Sparovek et al. [25] concludes that the expansion of sugarcane production cannot directly be considered as the main reason for deforestation. According to the OECD's study [2], most sugarcane plantations are not located near the Amazon region. Infrastructures that are required for ethanol production, are very scarce in the region. The study concludes that timber exploitation and high stocking rate are the main causes for deforestation. In addition, other forms of agriculture, besides sugarcane, are also expanding [26].

Although these studies do not show a direct link, it does not mean that the production of sugarcane cannot be indirectly linked to deforestation. Soybean production, which covers a far larger amount of agricultural land, occurs for a large part in the Center-West region of the country where the climate is ideal to produce sugarcane. 
Because of the bio-ethanol market, the soybean production may be replaced by sugarcane. Farmers who produce soybeans may move further to the North next to the Amazon region. This means that the production of sugarcane can indirectly lead to deforestation in the Amazon region. However, because the amount of land for soybean is far more than sugarcane, the indirect linkage to deforestation will not likely occur in the near future [24]. 


\subsection{Social impacts}

The production of sugarcane has not only environmental impacts, but there are also social impacts. Unfortunately, the impacts are not very positive. Although Brazil has ratified the main treaties and international instruments on human rights, these rights are not being respected in the sugarcane business.

First of all, the cultivation of sugarcane has a great impact on the labour conditions [2]. According to the Special Action Programme to combat Forced Labour of the International Labour Organization (ILO), "forced labour" is still a problem in Brazil [27]. Forced labour occurs mostly in the cattle ranching industry followed by the sugarcane industry. The conditions in which the labours have to work are comparable to slavery. ${ }^{5}$ They have to work long days while are low-paid. The overall working conditions have a negative effect on their health. The burnt farms cause them inhaled dust and smog that usually ends to inhalation diseases. A few reports [24,28] show that there are many cases of deaths due to such harmful working conditions. Furthermore, most of the harvest is still being done manually which has to be conducted only in dry seasons (May to October) that make it highly intensive [29].

Another problem for the Brazilian population is food insecurity. According to Action Aid $^{6}$ a global anti-poverty agency, the link between biofuels and hunger is strong. First of all, some strategic products like wheat, corn and sugar, are used also to produce biofuels in Brazil. Second, the land that is allocated for biofuels cannot be used for producing food or as grassland for cattle. Considering the food crisis in 2008, several studies have shown that biofuels were one of the main causes of increasing food prices as well [28].

\subsection{Economic impacts}

Due to the energy supply motive of the US and the EU, Brazil is capable to expand its sugarcane production. Brazil is planning to expand the bio-ethanol production by multiplying it by twelve. Accordingly, it is estimated that the total production of bioethanol by 2015 will be 205 billion litres per year, compared with the 17.7 billion litres in

\footnotetext{
${ }^{5} \mathrm{http}: / /$ www.ilo.org/sapfl/News/lang--en/WCMS_142253/index.htm

${ }^{6} \mathrm{http}: / /$ www.actionaid.org/main.aspx?PageID $=2$
} 
2006. The plan is made based on the growing demand for energy worldwide, especially in the States and the EU. ${ }^{7}$ The export of Brazilian bio-ethanol has increased from nearly 500 million litres in 2001 to 3.5 billion litres in 2006. Brazil has a lot to gain from this trade. The production of sugarcane is a labour intensive job and thereby creates more employment. The bio-ethanol production leads to an estimated 1 million jobs [2], and represents 3.5 percent of the total GDP [19].

The reason why bio-ethanol from Brazil is so popular is because Brazil has a competitive advantage compared with other bio-ethanol producers. The production cost for making bio-ethanol in the States is 40 percent higher than in Brazil. ${ }^{8}$ The improved technologies in the biofuels sector and the increasing price of fossil fuels make this sector relatively more competitive in comparison to fossil fuels [30].

\section{Main considerations}

Thus far discussed, there are some pros and cons when cultivating sugarcane for bioethanol. Indeed, there are some sorts of confusion on whether or not bio-ethanol is a good alternative for fossil fuels and whether bio-ethanol industry is beneficial for Brazil. What the case of Brazil shows is that the main actors regarding energy supply have to consider the implications of their policy, because the increasing demand has some consequences in multiple areas. As already mentioned, the US has raised taxes on the imported bioethanol. Similarly, the biofuels in the EU are heavily subsidized. According to ActionAid, the farmers in the EU received about $€ 1.4$ billion subsidies to produce biofuels. With the 10 percent target, this will raise up to $€ 4.2$ billion in 2020 . These subsidies are needed in order to compete at the biofuel market [28]. Thereby, it could be concluded that the motives of the US and the EU might not be very sincere.

The EU has come up with a plan that each member state has to have a National Renewable Energy Action Plan (NREAP) as a part of the RED. A recent study that analyzes the impacts of the NREAP shows that although the RED specifies sustainability criteria, it fails to take into account the indirect land use change. The change means that

\footnotetext{
${ }^{7}$ http://www.mo.be / 'Brazil, ethanol', (mondiaal nieuws) 27 oktober 2009. http://www.mo.be/artikel/brazilie-wil-ethanolproductie-vertwaalfvoudigen-tegen-2025 ${ }^{8} \mathrm{http} / / / \mathrm{www} . \mathrm{mo} . \mathrm{be} /$ 'Brazil, ethanol', (mondiaal nieuws) 27 oktober 2009. http://www.mo.be/artikel/brazilie-wil-ethanolproductie-vertwaalfvoudigen-tegen-2025
} 
the production of biofuels can indirectly cause additional deforestation and land degradation. This will result in an increase of greenhouse gas (GHG) emissions. The plans, as stated earlier, to expand biofuel use in Europe will require an expansion of cultivated agricultural land. According to the study, if all the land use impacts are included, the biofuels on the EU market will, on average, be 81 to 167 percent worse than fossil fuels for the climate. The study does make a note about bio-ethanol as well. The impact of sugarcane on the indirect land use change is less than for other crops [31]. These figures show an overall positive result though the Brazilian government has to keep monitoring the use and location of agricultural land.

In 2007, the United Nations came with a report about the sustainability of bio energy. According to the report, the expansion of the biofuels production could affect food security in four different ways: availability, accessibility, stability, and utilization that concern the availability of production resources, access to the market, stability of food security and utilization in terms of nutrients [32]. According to the World Bank's report [33], the increased biofuels production has contributed to a rise in food prices. The prices will continue to grow because of the energy security policies at the cost of food security. The Brazilian government contradicts these statements by saying that it will not affect food prices and thereby exacerbate food insecurity. They even say that the biofuel programs are applied to fight against poverty. The industry will likely create better access to the market due to the integration of small farmers into the production chain, which will lead to more income. Unfortunately, in 2004, almost 40 percent of the Brazilians were somehow exposed by food insecurity [32].

In an interview with Philip New, the director of British Petroleum (BP) stated that the production of bio-ethanol is not to blame on the increased food prices. According to agrarian reformists [34,35], world hunger happens mostly because of political failure. Due to them, there is enough food, but there is a distribution problem though some studies show that such statements might be biased [36,37,38,39], especially when bearing in mind that BP has invested over a billion in research and development of biofuels, mainly in Brazil. ${ }^{9}$

\footnotetext{
${ }^{9}$ http://english.unica.com.br/opiniao/show.asp?msgCode=916209CC-B504-49AF-BAF5-18462FD0F63A geraadpleegd op 10 November 2010.
} 
As stated earlier, the bio-ethanol production will lead to more jobs. However, the sugarcane industry has to be mechanized in order to eliminate (e.g.) the burning, which results in negative environmental impacts and unhealthy working conditions. The Brazilian Sugarcane Industry Association (UNICA) has estimated that 180,000 jobs in São Paulo will be lost due to this mechanisation [40]. FIAN even estimates that about 400,000 workers will become unemployed due to the mechanization of farming methods [33].

Additionally, although the forced labour is still taking place in the sugarcane industry, the Brazilian government has taken significant steps to eradicate the slavery working conditions. In 1995, the government established an Executive Group for the Repression of Forced Labour. The former government of President Lula da Silva even took it a step further. The government adopted a National Plan for the Eradication of Slave Labour, established the National Commission for the Eradication of Slave Labour, and recognized the responsibility of the Brazilian State in the violation of human rights [32]. This shows that efforts to fight against the forced labour are already made.

In a study conducted by the University of Utrecht in collaboration with the State University of Campinas, Brazil, it was investigated whether or not the production of bioethanol in Brazil is sustainable according to the Dutch sustainability criteria. The criteria correspond to the main issues discussed in this article, namely the reduction of $\mathrm{CO}_{2}$ emissions, ecological effects, the effects on food production, and the contribution to local prosperity and welfare. The main conclusion of the study was that there were no excessive reasons for São Paulo to fail from meeting the Dutch sustainability criteria. The study concluded that overall, the sugarcane production in São Paulo is a positive development action [41] although the conclusion stands on a few uncertainties and gaps, such as neglecting indirect impacts.

\section{Conclusion}

While it was previously proposed that the future of biofuels is very promising, not only as a way to solve the energy crisis but also environmental pollutions, currently, there is a growing debate that shows such fuels may not be as ideal as might have been hoped. Biofuels are blamed not to be environmentally friendly which may cause, amongst others, 
food insecurity. To produce bio-ethanol in Brazil, large amounts of land are needed for the production of sugarcane, which may cause deforestation although some believe that the Amazon's deforestation cannot directly be linked to bio-ethanol production. Furthermore, some reports on the forced labour raise our concern. The mechanization of the sugarcane industry would also exacerbate unemployment rate in the Brazilian agrirural sector. Overall, at the current manner, although bio-ethanol production in Brazil might be more environmentally friendly than fossil fuels, it might socio-economically be hazardous. It highlights that the production of such biofuels in this country should carefully be monitored by all the three discussed aspects of sustainability.

\section{References}

[1] M.A. Keyzer, M.D. Merbis, R.L. Voortman, The biofuel controversy, De Economist 156 (2008) 507-527.

[2] GAIN Report, Brazil Biofuels Annual 2010, USDA Foreign Agricultural Service. GAIN Report BR10006, 2010.

[3] IEA (International Energy Agency), Biofuels for Transport. An International Perspective, Paris, International Energy Agency, 2004.

[4] J.C. Escobar, E.S. Lora, O.J. Venturini, E.E. Yanez, E.F. Castillo, O. Almazan, Biofuels: Environment, technology and food security, Renewable and Sustainable Energy Reviews 13 (2009) 1275-1287.

[5] K.R. Jegannathan, E.-S. Chan, P. Ravindra, Harnessing biofuels: A global Renaissance in energy production? Renewable and Sustainable Energy Reviews 13 (2009) 2163-2168.

[6] M.E.D. de Oliveira, B.E. Vaughan, E.J. Rykiel Jr, Ethanol as fuel: Energy, carbon dioxide balances, and ecological footprint, BioScience 55 (2005) 593- 602.

[7] RFA, The Gallagher Review of the Indirect Effects of Biofuels Production, Renewable Fuels Agency (RFA), East Sussex, 2008.

[8] M.S. de Paula Gomes, M.S.M. de Araujo, Bio-fuels production and the environmental indicators, Renewable and Sustainable Energy Reviews 13 (2009) 2201-2204. 
[9] P. Zuurbier, J. van de Vooren, (Eds.), Sugarcane ethanol: Contributions to climate change mitigation and the environment. Wageningen Academic Publishers, Wageningen, 2008.

[10] L. Luo, E. van der Voet, G. Huppes, Life cycle assessment and life cycle costing of bioethanol from sugarcane in Brazil, Renewable and Sustainable Energy Reviews 13 (2009) 1613-1619.

[11] M. Gauder, S. Graeff-Hönninger, W. Claupein, The impact of a growing bioethanol industry on food production in Brazil, Applied Energy 88 (2011) 672-679.

[12] J. Hall, S. Matos, L. Severino, N. Beltrão, Brazilian biofeuls and social exclusion: Established and concentrated ethanol versus emerging and dispersed biodiesel, Journal of Cleaner Production 17 (2009) 577-585.

[13] E. Krivonos, M. Olarreaga, Sugar prices, labor income, and poverty in Brazil, Economía 9 (2006) 95-123.

[14] M. Lehtonen, Social sustainability of the Brazilian bioethanol: power relations in a centre-periphery perspective, Biomass and Bioenergy 35 (2011) 2425-2434.

[15] E. Smeets, M. Junginger, A. Faaij, A. Walter, P. Dolzan, Sustainability of Brazilian bio-ethanol. Copernicus Institute, Department of Science, Technology and Society Report NWS-E-2006-110, Utrecht, 2006.

[16] A. Walter, P. Donzan, O. Quilodrán, J.G. de Oliveira, C. da Silva, F. Piacente, A. Segerstedt, Sustainability assessment of bio-ethanol production in Brazil: considering land use change, GHG emissions and socio-economic aspects. Energy Policy 39 (2010) 5703-5716.

[17] D. Yergin, Ensuring energy security. Foreign Affairs 85 (2006) 69-82.

[18] OECD, World Energy Outlook, International Energy Agency. Paris: France, 2008 Available on: http://siteresources.worldbank.org/NEWS/Resources/risingfoodprices_backgroun dnote_apr08.pdf

[19] OECD, Biofuels, Linking Support to Performance, Paris: International Transport Forum, 2007. 
[20] The Rio Times, US Opens Market for Brazilian Ethanol. By Sam Cowie, December 27, 2011. Available on: http://riotimesonline.com/brazil-news/rio-business/usopens-market-for-brazilian-ethanol/

[21] S. Branford, Biofuel power games, New Statesman 136 (2007) 18.

[22] J.H. Ulmanen, G.P.J. Verbong, R.P.J.M. Raven, Biofuel developments in Sweden and the Netherlands Protection and socio-technical change in a long-term perspective, Renewable and Sustainable Energy Reviews 13 (2009) 1406-1417.

[23] G. Lincoln, Brazil's Second Change. En Route toward the First World. Washington DC: Brookings Institution Press, 2001.

[24] L.A. Martinelli, S. Filoso, Expansion of sugarcane ethanol production in Brazil: environmental and social challenges, Ecological Applications 18 (2008) 885-898.

[25] G. Sparovek, A. Barretto, G. Berndes, S. Martins, R. Maule, Environmental, landuse and economic implications of Brazilian sugarcane expansion 1996-2006, Mitigation and Adaptation Strategies for Global Change 14 (2008) 285-298.

[26] E.F. De Almeida, J.V. Bomtempo, C.M. de Souza E Silva, The Performance of Brazilian Biofuels: An Economic, Environmental and Social Analysis, Paris, France: OECD, International Transport Forum, 2007.

[27] P. Belser, M. de Cock, F. Mehran, ILO Minimum Estimate of Forced Labour in the World, Nondiscrimination. Paper 7, 2005. Available on: http://digitalcommons.ilr.cornell.edu/nondiscrim/7

[28] T. Rice, Meals per Gallon. The Impact of Industrial Biofuels on People and Global Hunger, London, UK: ActionAid, 2010.

[29] M. Uriarte, C.B. Yackulic, T. Cooper, D. Flynn, M. Cortes, T. Crk, G. Cullman, M. McGinty, J. Sircely, Expansion of sugarcane production in São Paulo, Brazil: implications for fire occurrence and respiratory health, Agriculture, Ecosystems and Environment 132 (2009) 48-56.

[30] OECD, Biofuel Support Policies. An Economic Assessment, Paris: OECD, 2008.

[31] C. Bowyer, Anticipated Indirect Land Use Change Associated with Expanded Use of Biofuels and Bioliquids in the EU. An Analysis of the National Renewable Energy Action Plans, 2010, Available on: http://www.ieep.eu/publications/pdfs/2010/iluc_analysis.pdf 
[32] S.M. Suárez, U. Bickel, F. Garbers, L. Goldfarb, V. Schneider, Agrofuels in Brazil. Heidelberg, Germany: FIAN International. Sustainable Bioenergy: A Framework for Decision Makers, United Nations, 2008.

[33] World Bank, Rising Food Prices: Policy Options and World Bank Response, 2008, Available on: http://siteresources.worldbank.org/NEWS/Resources/risingfoodprices_backgroun dnote_apr08.pdf

[34] S. George, How the Other Half Dies. The Real Reasons for World Hunger, Penguin books Ltd, New York, 1986.

[35] E. Boserup, The Conditions of Agricultural Growth. The Economics of Agrarian Change under Population Pressure, Transaction Publishers, New Jersey, 2005.

[36] H. Azadi, H. Ho, Genetically modified and organic crops in developing countries: A review of options for food security, Biotechnology Advances 28 (2010) 160-168.

[37] H. Azadi, N. Talsma, P. Ho, K. Zarafshani, GM crops in Ethiopia: A realistic way to increase agricultural performance? Trends in Biotechnology 29 (2011) 6-8.

[38] H. Azadi, S. Schoonbeek, H. Mahmoudi, B. Derudder, P. De Maeyer, F. Witlox, Organic agriculture and sustainable food production system: Main potentials, Agriculture, Ecosystems \& Environment 144 (2011) 92- 94.

[39] S. Bazuin, H. Azadi, F. Witlox, F. Application of GM crops in Sub-Saharan Africa: Lessons learned from Green Revolution, Biotechnology Advances 29 (2011) 908912.

[40] A.J. Nelson, Climate Change and Biofuels, Washington D.C., Woodrow Wilson International Center for Scholars. Brazil Institute, 2009.

[41] E. Smeets, M. Junginger, A. Faaij, A. Walter, P. Dolzan, Sustainability of Brazilian bio-ethanol. Copernicus Institute, Utrecht, The Netherlands \& State University of Campinas, São Paulo, Brazil, 2006. 